\title{
Evaluation of traits related to bread wheat (Triticum aestivum L.) root in drought tolerance applied at the beginning of vegetative and reproductive stages
}

\author{
Arman ESKANDARI SHAHRAKI ${ }^{1,2}$, Mohammad-Mehdi SOHANI ${ }^{1}$, Sadollah HOOSHMAND ${ }^{3}$, Ali \\ AALAMI ${ }^{1}$, Habibullah SAMIZADEH ${ }^{1}$
}

Received April 10, 2021; accepted November 29, 2021.

Delo je prispelo 10. aprila 2021, sprejeto 29. novembra 2021

\begin{abstract}
Evaluation of traits related to bread wheat (Triticum aestivum L.) root in drought tolerance applied at the beginning of vegetative and reproductive stages

Abstract: Roots play an important role in wheat grain yield, especially under drought stress conditions. To investigate root characteristics under drought stress conditions in bread wheat, 90 lines F10 obtained from the crossing ('Yecora Rojo' $\times$ 'Chinese Spring') randomly with the parents of the population were examined. The study was conducted in the form of a splitplot design with a randomized complete block base in three conditions including: 1 . no stress, 2 . application of drought stress at the beginning of the vegetative stage, and 3. application of drought stress at the beginning of the reproductive stage. The results showed, interaction between genotype and condition of drought was significant for all root-related traits, except shallow root dry mass, at the level of $1 \%$ probability. The response of root-related traits to different types of drought stress was very complex. The longest root length, decrease for $13.3 \%$ was during stress at the beginning of the vegetative stage in comparison to non-stress conditions, while the same trait increased for $4.9 \%$ during stress at the beginning of the reproductive stage, comparison to non-stress conditions. The results of principal component analysis under non-stress conditions showed that by considering the distribution of genotypes compared to the first two components, genotypes can be identified that have more yield with the proper root condition and vice versa.
\end{abstract}

Key words: deep root; drought tress; main components; shallow root; tolerance index
Ovrednotenje lastnosti korenin krušne pšenice (Triticum aestivum $\mathrm{L}$.) povezanih $\mathrm{s}$ sušnim stresom $\mathrm{v}$ začetku vegetativne in reproduktivne faze razvoja

Izvleček: Korenine imajo pomembno vlogo za pridelek zrnja pšenice, še posebej v razmerah suše. Za preučevanje značilnosti korenin krušne pšenice $v$ razmerah sušnega stresa je bilo pridobljenih 90 linij F10 iz naključnih križanj med starševskima sortama Yecora Rojo in Chinese Spring. Raziskava je bila izvedena kot poskus z deljenkami kot popolni naključni bločni poskus v treh stresnih razmerah: 1 . brez stresa, 2. sušni stres na začetku vegetativne faze razvoja in 3. sušni stres na začetku reproduktivne faze razvoja. Rezultati so pokazali, da je bila interakcija med genotipom in razmerami stresa značilna za vse s koreninami povezane lastnosti na ravni $1 \%$ verjetnosti, razen za suho maso plitvih korenin. Odziv s koreninami povezanih lastnosti na različne vrste sušnega stresa je bil zelo kompleksen. Zmanšanje dolžine najdaljših korenin za 13,3 \% v primerjavi s kontrolo je bilo, ko je sušni stres nastopil na začetku vegetativne faze razvoja med tem, ko se je isti parameter povečal za 4,9\% ob nastopu sušnega stresa na začetku reproduktivne faze razvoja $v$ primerjavi $z$ nestresnimi razmerami. Rezultati analize glavnih component iz poskusa $\mathrm{v}$ nestresnih razmerah so pokazali, da bi z upoštevanjem razvrstitve genotipov glede na dve prvi komponenti te lahko razdelili na tiste, ki imajo več pridelka in primeren koreninski sistem in obratno.

Ključne besede: globoke korenine; sušni stres; glavne komponenete; plitve korenine; tolerančni indeks

1 Department of Agriculture and Plant Breeding, Guilan University, Rasht, Iran

2 Corresponding author, e-mail: ph.d.eskandari@gmail.com

3 Department of Agriculture and Plant Breeding, Shahrekord University, Shahr-e-kord, Iran 


\section{INTRODUCTION}

Water scarcity is a serious challenge to survival, especially in arid and semi-arid regions. Different climatic models predict that drought stress will increase in frequency and intensity and this will confirm the shortage of available water in the future (Nadeem, 2019). Therefore, it seems necessary to understand the consequences of these changes on the production of different types of crops (Shanker, 2014). To date, many traits such as: number of seeds per plant, plant biomass, thousand-seed mass (Ghassemi-Golezani, 2018), grain yield, harvest index (Kadam, 2012), relative leaf water content, amount of tissue lost water, leaf wax content, leaf thickness, stomatal characteristics (Heidari, 2012), number of days to spike, number of days to physiological maturity, plant shading temperature, green content of the plant (Hasani, 2016), to study how crops react to drought stress in the field and laboratory has been studied. Most of the collected information about drought stress is related to traits that consider conditions above the soil surface and limited attention has been paid to plant root traits. Ignoring the selection of root traits in wheat is mainly due to problems in measuring the traits of the root system and how the roots are distributed (Richards, 2008). Under water restriction conditions, plant growth is directly determined by the ability to absorb and convert water into plant biomass (Jin et al., 2018), therefore the ability of roots to grow under drought stress conditions is an adaptive feature for plants, especially in rainfed conditions and with limited irrigation (Dalal, 2018). Root architecture is one of the most promising features for drought stress and can be used positively in drought resistance breeding programs. This feature enables the plant to extract water more efficiently from deeper soil layers, under very dry environments (Nadeem, 2019). Therefore, genetic modification of plants to have an effective root system, with all its problems, is very important for optimal production in rainfed conditions and with limited water (Kadam, 2012).

Hammer et al. (2009) showed that root architecture and its associated water uptake are more important than canopy architecture and plant light uptake for biomass and plant performance in high-density vessels. Advances in water uptake from subsoil by rainfed wheat can make a significant contribution to its yield (Jin, 2015b). In order for wheat to be highly productive, it is necessary to remove barriers to plant growth by supporting the root system that is effective in absorbing water and nutrients (Jin, 2015a). Drought tolerance depends on the plant's ability to avoid water leakage from plant tissues, which is affected by root architecture, including: increased root length, root density, and deep rooting, because the plant can much more than the soil to search for water absorption (Sofi, 2018).

Gao and Lynch (2016) reported that they are very effective in tolerating drought stress, increasing rooting depth, and subsequently improving water uptake from deeper soil levels. Also, traits such as root thickness, root dry mass, root volume and root density have high heritability that can have a positive effect on drought stress tolerance (Kadam, 2012). Axial roots are a key element in the plant root phenotype. Axial roots are the main structure of root biomass and form a framework for lateral root growth and therefore have a significant effect on lateral root penetration into deeper soil slopes (Gao and Lynch, 2016). On the other hand, the usefulness of a strong root system to increase yield in environments without water stress is much more effective than the same type of root system in drought stress conditions, because a strong root system may reduce the risk of depletion of soil water before completion, increase the grain filling stage (Sofi, 2018).

In general, according to different reports for the root system, the root reaction under drought stress conditions is very complex and it is very difficult to maintain a balance between traits to modify its characteristics. However, roots are a semi-latent plant that is difficult to ignore their importance in yield (Koolachart et al., 2013; Bardgett et al., 2014). At present, the study of root systems and their importance in water and nutrient uptake and their role in drought stress resistance has been considered by agricultural researchers. The study of plant root systems is very limited due to the difficulties associated with root studies, including observation, measurement of related traits and their manipulation in the field and the use of destructive methods (Sharma et al., 2011; Thangthong et al., 2016).

Carrying out agronomic and physiological studies related to root systems in wheat and their results can be very useful in breeding programs to promote, adapt and stabilize grain yield of new wheat cultivars. As a result, identifying and understanding root characteristics for crop development is essential in stressful conditions (Jin et al., 2018). Due to the scarcity of water resources in the country and facing a drought crisis, it is necessary to pay attention to valuable gene resources for use in the wheat breeding program. Identifying beneficial gene sources and genes that control drought tolerance and improving some traits and creating ideal types will play an important role in the development of wheat breeding programs. Therefore, the purpose of this study was to investigate the important root-related traits in recombinant (RIL) layers of bread wheat in tolerance to drought stress applied at the beginning of the vegetative and reproductive stages. 


\section{MATERIALS AND METHODS}

From 156 recombinant F10 inbred lines from the cross between two Chinese Spring cultivars as female parents and 'Yecora Rojo' as male parents, 90 lines were randomly selected and named with RIL letters and genotype number. This population was prepared by single seed selection. The two parents of the population differed significantly in some drought tolerance characteristics such as carbon isotope discrimination and other agronomic and morphological traits (Ehdaie and Waines, 1994). In addition to 90 recombinant inbred lines, the parents of the population and four cultivars named Sorkhatakhm, Pishtaz, Kalhidari and Aflak were also examined in this research. This study was conducted in the form of a splitplot design with a randomized complete block base in three conditions including: 1 . no stress, 2 . application of drought stress at the beginning of the vegetative stage (code 30 of Zadoks growth scale), and 3. application of drought stress at the beginning of the reproductive stage or boots swollen (code 45 of Zadoks growth scale). Since accurate evaluation of root characteristics in field conditions is almost impossible, an attempt was made to use near-field and controllable conditions in this field.

First, a part of the field was selected, then the surface soil of that area was collected to a depth of $35 \mathrm{~cm}$ from the ground. In the same area, a canal $1 \mathrm{~m}$ deep, $2 \mathrm{~m}$ wide and $25 \mathrm{~m}$ long was dug to place the planting tubes. In order to implement the experimental design, plastic pipes with a diameter of $12 \mathrm{~cm}$ and a length of one meter were prepared and the pipes with a homogeneous combination of soil containing $35 \%$ of arable soil collected from the field and $65 \%$ of sand (in order to facilitate root tissue separation), was filled and used as an experimental unit. At the end of the plastic pipes, there were holes for water to drain. Also, the soil prepared for filling the culture tubes was sampled and sent to the laboratory to determine the field capacity (FC), wilting point (PWP) and other characteristics, and the soil characteristics used are given in Table 1.

In each experimental unit, three seeds of one genotype were planted and after confirming the establishment of plants, one plant was maintained and the rest were removed. Drought stress was applied in two phenological stages including: beginning of the vegetative stage (code 30 of Zadoks growth scale), and beginning of the reproductive stage or boots swollen (code 45 of Zadoks growth

Table 1: The soil profile used to fill the planting tubes

\begin{tabular}{lllllll}
\hline $\begin{array}{l}\text { Sand } \\
(\%)\end{array}$ & $\begin{array}{l}\text { Silt } \\
(\%)\end{array}$ & $\begin{array}{l}\text { Clay } \\
(\%)\end{array}$ & $\begin{array}{l}\text { EC } \\
\left(\mathrm{ds} . \mathrm{m}^{-1}\right)\end{array}$ & $\begin{array}{l}\mathrm{FC} \\
(\%)\end{array}$ & $\begin{array}{l}\text { P.W.P } \\
(\%)\end{array}$ & $\mathrm{pH}$ \\
\hline 70 & 13.5 & 16.5 & 3.39 & 37.1 & 15.4 & 7.4 \\
\hline
\end{tabular}

scale) with complete cessation of irrigation, after each line reached the desired phenological stage. Under conditions without drought or normal stress, irrigation was done when the volume percentage of moisture reached about $70 \%$ of the soil field capacity within the cultivation pipes. Volumetric moisture content was measured by PMS-714 humidity meter every three days in stress-free treatment. In order to properly feed the wheat, the fertilizer regime used for each cultivation tube, under stress and non-stress conditions, included $500 \mathrm{ml}$ of Hoogland $50 \%$ fertilizer solution, which was added to each tube in two stages and $250 \mathrm{ml}$ in each stage, before reaching Added to the desired phenological stages for stress application and irrigation time. After physiological examination of most recombinant inbred lines and before harvest, the height of the last leaf from the soil surface was measured. To obtain healthy roots and prevent damage to them, the planting tubes were gently removed from the pit and placed on a horizontal platform, then the tubes were cut and the soil mass inside them was carefully removed. The tubes containing the remaining soil that had not been removed from the roots were then gently inserted into the tub to remove the sand around the roots. The washed roots were placed on a plastic surface and the traits related to the roots included: the size of the longest root, the mass of the shallow roots (zero to $30 \mathrm{~cm}$ depth), the mass of the deep roots (deeper depth). $(30 \mathrm{~cm})$, root biomass, root to biomass ratio of total plant, root to shoot ratio, plant height, stem dry mass, panicle length, panicle mass, number of seeds per panicle, seed mass per plant, plant biomass, mass thousands of seeds and biological yield were measured. For more detailed information on the tolerance or susceptibility of genotypes to drought stress, stress tolerance indices, which in many studies had a significant correlation with yield, including mean productivity (MP) indices, geometric mean productivity (GMP) and stress tolerance index (STI) were calculated and evaluated.

$$
M P=\frac{Y_{s}+Y_{p}}{2} \quad G M P=\sqrt{(Y s)(Y p)} \quad S T I=\left(\frac{Y p}{Y p}\right)\left(\frac{Y s}{\overline{Y s}}\right)\left(\frac{\overline{Y s}}{\overline{Y P}}\right)=\frac{\left(Y_{p}\right)\left(Y_{s}\right)}{(\overline{Y p})^{2}}
$$

Yp and Ys yield genotypes under normal and stress conditions, respectively.

Descriptive statistics, analysis of variance, evaluation of genotype response based on tolerance or drought sensitivity indices, ranking of genotypes based on tolerance indices at all levels of stress, grouping of genotypes based on average rank index and checking the accuracy of grouping by independent comparison test, was done. Euclidean distance was used to measure the dissimilarity between genotypes by hierarchical clustering method (average linkage method). The main components for 
each of the stress-free and stress-free environments were analyzed.

\section{RESULTS AND DISCUSSION}

The results of analysis of variance from the study of traits are presented in Table 2. According to the results, it was found that there is a significant difference between genotypes in terms of all root-related traits at the level of one percent probability. Also, the interaction of genotype under environmental conditions was significant for all root traits, except shallow root dry mass, at the level of $1 \%$ probability. Bardgett et al. (2014) reported that diversity in root traits not only exists between different species and cultivars, but also the diversity of root traits within the species is very high, and this has the potential for plants. It helps to show different abilities in absorbing water and nutrients, and there is a lot of evidence that some root-related traits respond quickly to environmental changes. In another study of drought stress on wheat, the difference between maximum root length, total root biomass, root biomass up to a depth of $30 \mathrm{~cm}$ and root biomass greater than $30 \mathrm{~cm}$ depth, the difference have shown significance (Kadam et al., 2012).

Also Sofi et al. (2018) showed that drought stress significantly affects root biomass, rooting depth, total root length, root volume. The results of analysis of variance of yield-related traits and yield components showed a significant difference in the level of $1 \%$ probability between genotypes and also the existence of genotype interaction at drought stress levels for all these traits (Table 2).

This indicates genetic diversity as well as different trends in the response of genotypes to drought stress conditions. Sinha et al. (2019) reported that there is an inverse relationship between drought stress levels and yield.

Among the studied traits, the response of root-related traits to different types of drought stress was of particular importance (Table 3). The longest root decrease by $13.3 \%$ compared to non-stress conditions during stress was determined at the beginning of the vegetative stage, while the same trait increased by $4.9 \%$ compared to non-stress conditions during stress at the beginning of the reproductive stage. Root system-related studies that emphasize grain yield in wheat have reported a variety of positive, negative, and neutral relationships (Sofi et al., 2018).

In 2018, study on wheat roots under drought stress, drought stress significantly increased the root length of some genotypes (Dalal et al., 2018). During the application of stress at the beginning of the vegetative stage, the dry mass of shallow roots (depth between 0 to $30 \mathrm{~cm}$ ) decreased by $2.8 \%$ compared to the non-stress conditions. The main feature of shallow roots, which are located at upper soil levels, is mainly the absorption of water-soluble nutrients, and the performance of roots with a penetration depth of more than $30 \mathrm{~cm}$, in most cases water absorption from the deeper soil levels. (Ehdaie et al., 2016). Root biomass decreased by $13.1 \%$ compared to non-stress conditions during stress application at the beginning of vegetative stage, while the same trait shows a $3.4 \%$ increase compared to non-stress conditions during stress application at the beginning of reproductive stage (Table 3 ).

Since root biomass was the result of the total dry mass of shallow and deep roots and the dry mass response of shallow roots to both drought stress conditions was decreasing, so the increase of root biomass during stress application at the beginning of reproductive stage. It can be caused by the increase in dry mass of deep roots. Biomass is a root trait that has been proposed as an important feature in drought stress resistance and yield stability in bread wheat in places with variable moisture regimes (Ehdaie et al., 2012). In the ratio of root biomass to total biomass of wheat plant, a $51.9 \%$ increase in this proportion was observed with the application of stress at the beginning of the vegetative stage and $29.6 \%$ with the application of stress at the beginning of the reproductive stage compared to non-stress conditions (Table 3 ). The increase in the amount of this proportion during drought stress is due to the destructive effects of stress on plant biomass (biomass above the soil surface) which is part of the total plant biomass and is at the denominator of this proportion. The root-to-shoot ratio showed an increase of $94.7 \%$ in terms of stress at the beginning of the vegetative stage and $60.5 \%$ in terms of stress at the beginning of the reproductive stage compared to non-stress conditions. Stunting of plant shoots including shoots and stems is one of the primary effects of drought stress, which occurs indirectly through chemical signaling from root to stem (Jin et al., 2015a). Some reports suggest that the root-to-shoot ratio can be an important feature for drought tolerance, so that the higher the root-to-shoot ratio, the higher the plant's tolerance to drought stress. A study on shoot and root characteristics of maize hybrids in drought tolerance showed that irrigated diets had less effect on root dry mass compared to stem dry mass (Jin et al., 2018). In the study of root-related traits, the response of the wheat plant was very different and even contradictory in some cases due to the stressful stage of growth. 


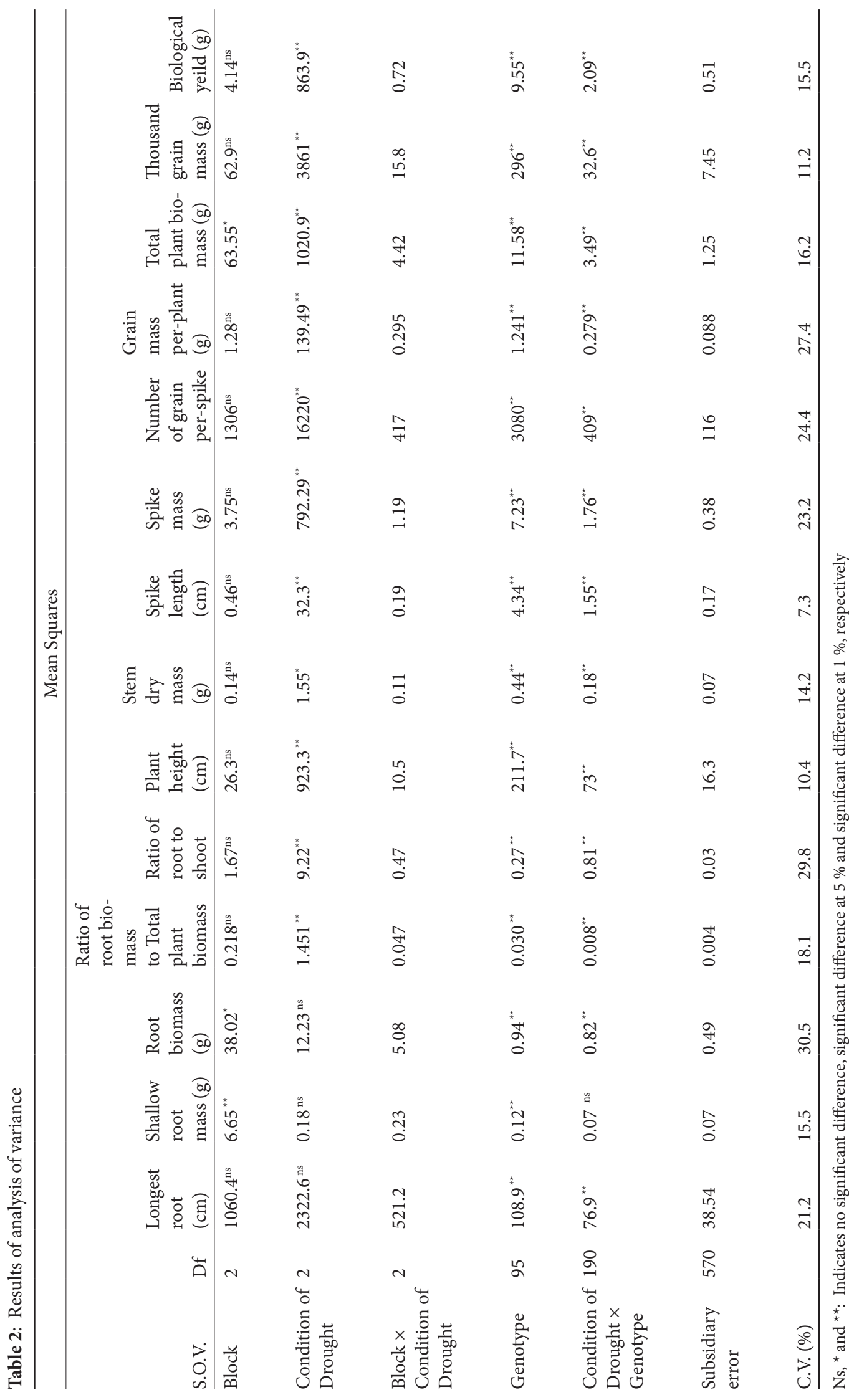




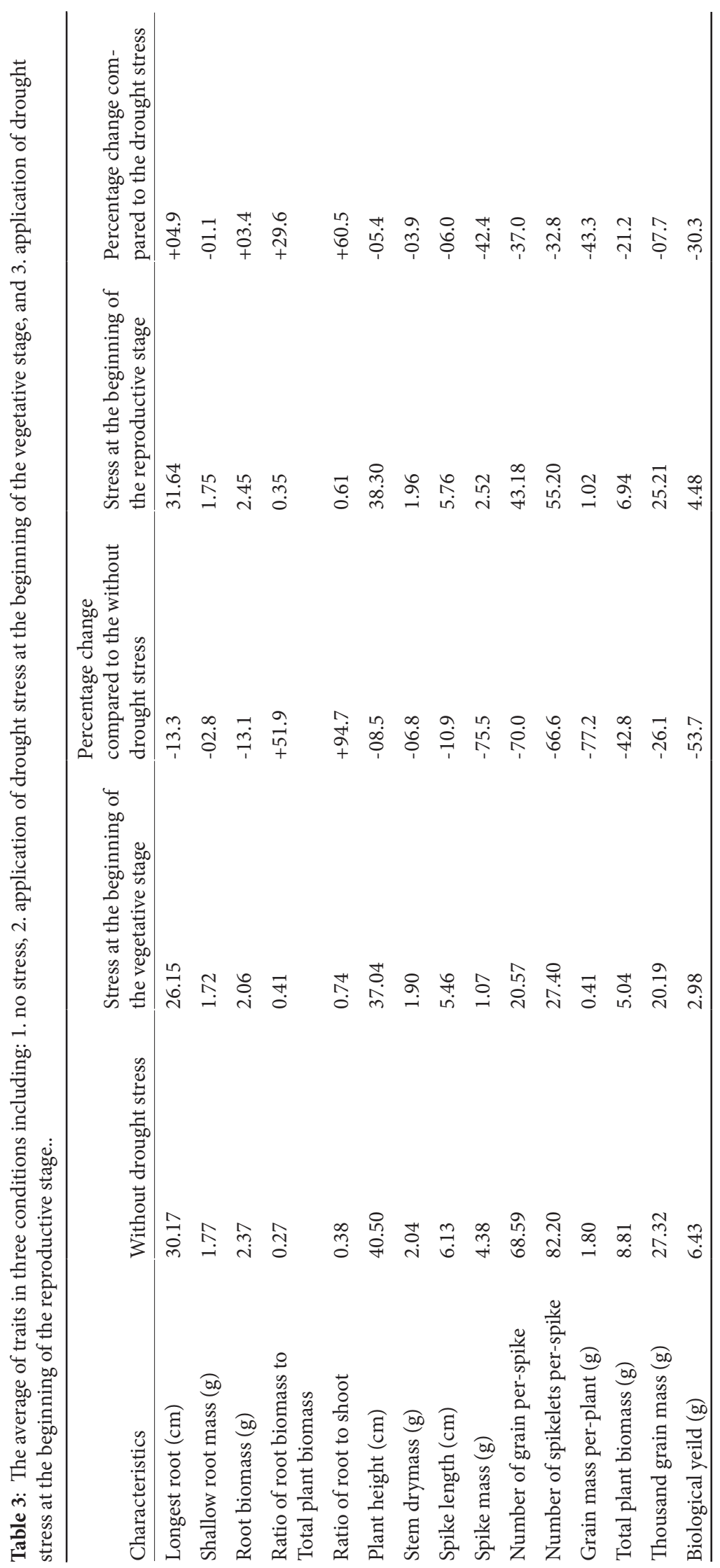

6 | Acta agriculturae Slovenica, 117/4 - 2021 
In order to investigate the relationship between the measured traits, the correlation coefficient between the traits was calculated and interpreted (Table 4). According to the results, a positive and very significant relationship at the level of $1 \%$ probability was between the yield (grain mass per plant) with plant biomass $\left(0.89^{* *}\right)$. Also, a very significant negative relationship was observed between yield (grain mass per plant) with the ratio of root biomass to total plant biomass $\left(0.71^{* *}\right)$ and ratio root to shoot biomass $\left(0.65^{* *}\right)$. Correlation table coefficients show a positive and very significant relationship between the longest root with root biomass $\left(0.75^{* *}\right)$, total deep root length $\left(0.55^{* *}\right)$ at the level of $1 \%$ probability.

Contrary to the results of this study, Kadam et al.(2012) showed that root biomass had a significant correlation with all measured traits except the longest root and no correlation was observed between root biomass and the longest root. In another study to locate quantitative traits related to root and shoot characteristics in a population of recombinant inbred lines of spring wheat, it was reported that between plant biomass and number of seeds per spikelet, dry mass of shallow roots, dry mass of deep roots and root biomass, there is a correlation at the level of $1 \%$ probability (Ehdaie et al., 2016).

Since grain yield in genotypes may be independent of each other under normal and stress conditions, the tolerance or susceptibility index to stress was used to distinguish genotypes that responded better to stress conditions. The use of these indices was the identification and selection of genotypes that have relatively high yields under both normal and stress conditions. Studies show that the average productivity indices (MP), geometric mean productivity (GMP) and stress tolerance index (STI), due to high correlation with grain yield, are suitable for identifying high yield genotypes under normal conditions, mild stress and severe drought stress (Ali and El-Sadek, 2016; Khosravi et al., 2020). In this study, the genotypes that showed the highest MP, GMP and STI and also had high yield, drought tolerant genotypes were considered and vice versa. After ranking the genotypes based on all three indices of tolerance or sensitivity to stress, the average ratings obtained for each genotype were also calculated as the mean rank index (RM). Correlation coefficients between the three indices of drought tolerance and yield under stress conditions at the beginning of the vegetative and non-stress stages showed that there is a positive and significant correlation at the level of one percent probability between all indices of stress tolerance and yield. Therefore, it seems that the indicators used in this study can be effective in identifying and differentiating high-yield genotypes under drought and non-stress conditions. Since the accuracy of independent comparison test is higher than independent comparison test and practical analysis test of observations or division of effects of treatments, so in order to group genotypes based on average rank index and measure the validity of grouping accuracy, the comparison test were used independently. First, the genotypes were ranked from 1 to 96 based on the mean RM (T) rank index. Then genotypes with ranks between one and 48 were placed in the first group and the rest of the genotypes were classified from 49 to 96 in the second group. For independent comparison test, the first group was given a coefficient of +1 and the second group was given a coefficient of -1 . Then, the independent comparison test between the first and second groups was performed according to the measured

Table 4: Correlation between the measured traits in all three stress conditions including: 1. no stress, 2. application of drought stress at the beginning of the vegetative stage, and 3. application of drought stress at the beginning of the reproductive stage

\begin{tabular}{|c|c|c|c|c|c|c|c|}
\hline Characteristics & $\begin{array}{l}\text { Longest } \\
\text { root } \\
(\mathrm{cm})\end{array}$ & $\begin{array}{l}\text { Root } \\
\text { biomass } \\
(\mathrm{g})\end{array}$ & $\begin{array}{l}\text { Total deep } \\
\text { roots length } \\
(\mathrm{cm})\end{array}$ & $\begin{array}{l}\text { Ratio } \\
\text { of root } \\
\text { biomass } \\
\text { to Total } \\
\text { plant } \\
\text { biomass }\end{array}$ & $\begin{array}{l}\text { Grain } \\
\text { mass per- } \\
\text { plant (gr) }\end{array}$ & $\begin{array}{l}\text { Total } \\
\text { plant } \\
\text { biomass (g) }\end{array}$ & $\begin{array}{l}\text { Ratio of } \\
\text { root to } \\
\text { shoot }\end{array}$ \\
\hline Longest root $(\mathrm{cm})$ & 1.00 & $0.75^{* *}$ & $0.55^{* *}$ & $0.29^{\text {ns }}$ & $0.19^{\text {ns }}$ & $0.49^{*}$ & $0.28^{\mathrm{ns}}$ \\
\hline Root biomass (g) & & 1.00 & $0.48^{*}$ & $0.47^{*}$ & $0.18^{\mathrm{ns}}$ & $0.56^{* *}$ & $0.47^{*}$ \\
\hline Total deep roots length $(\mathrm{cm})$ & & & 1.00 & $0.13^{\text {ns }}$ & $0.03^{\mathrm{ns}}$ & $0.17^{\mathrm{ns}}$ & $0.12^{\mathrm{ns}}$ \\
\hline $\begin{array}{l}\text { Ratio of root biomass to Total } \\
\text { plant biomass }\end{array}$ & & & & 1.00 & $-0.71^{* *}$ & $-0.42^{*}$ & $0.96^{* *}$ \\
\hline Grain mass per-plant (g) & & & & & 1.00 & $0.89^{* *}$ & $-0.65^{* *}$ \\
\hline Total plant biomass (g) & & & & & & 1.00 & $-0.37^{\mathrm{ns}}$ \\
\hline Ratio of root to shoot & & & & & & & 1.00 \\
\hline
\end{tabular}

$\mathrm{Ns},{ }^{*}$ and ${ }^{* *}$ : Indicates no significant difference, significant difference at $5 \%$ and significant difference at $1 \%$, respectively 
data related to grain yield in plant genotypes. The results of the independent comparison test between the two groups are given in Table 5. The results showed a significant difference in the level of $1 \%$ probability between the two groups based on the mean rank index.

Mohammadi and Abdullahi (2017) also reported the use of a stress tolerance index could not lead breeders to the best option and genotypes should be selected based on a combination of several tolerance indices or sensitivity to provide a more practical criterion for improving stress tolerance traits.

Determining the size of the inbred lines and proximity to each other, as well as increasing productivity in effective parenting, can reduce breeding volume, costs, and time. To separate the genotypes, cluster analysis was used by Euclidean distance to measure the dissimilarity between genotypes by hierarchical clustering method (average linkage method), and finally the genotypes were divided into four main groups (Figure 1). The first group consists of two subgroups, which subgroup (a) includes eight genotypes with the names of RIL19, RIL46, RIL51, RIL62, RIL64, RIL89, RIL114 and RIL164 and subgroup (b) contains 63 genotypes. It seems that the reason for the divergence of the two subgroups from each other is how the genotypes in the group react to drought stress for grain yield per plant. So that the genotypes of subgroup (a) in all three conditions of the experiment were weak in terms of grain yield and most of them in terms of yield rank under non-stress conditions, drought stress at the beginning of vegetative stage and drought stress at the beginning of vegetative stage. Are at the bottom of the table. On the other hand, although in subgroup (b) grain yield per plant was very diverse and in some cases to some extent, but in general grain yield per plant genotypes in this subgroup, in all three conditions without stress and application of two The type of drought stress at the beginning of the vegetative and reproductive stages was favorable and was higher than the average population of the studied genotypes. The second group consists of eighteen genotypes named Aflak, RIL8, RIL9, RIL10, RIL16, RIL23, RIL48, RIL67, RIL76, RIL79, RIL82, RIL87, RIL112, RIL113, RIL122, RIL137, RIL150 and RIL151. The mean rank index of most genotypes in this group was in the upper half of the ranking table during the stress application conditions at the beginning of the vegetative stage and during the stress application conditions at the beginning of the reproductive stage.

This indicates that the genotypes in this group did not respond well to drought stress in terms of tolerance or susceptibility to stress. The genotypes of this group in terms of the average of some measured traits such as: longest root size, root biomass and plant biomass, in all three conditions of the experiment, had higher ranks than the average of all studied genotypes. In other words, these genotypes had a favorable response to drought stress in terms of the average of the mentioned traits. In the third group, only one genotype named RIL35 was included. The fourth group consisted of six ruby egg genotypes, RIL117, RIL118, RIL141, RIL146 and RIL163. Seed yield per plant in this group was very low and weak compared to other genotypes under non-stress conditions, drought stress at the beginning of the vegetative stage and drought stress at the beginning of the reproductive stage. However, there were good potentials among the genotypes of this group in terms of shallow root dry mass, root biomass, plant biomass and longest root.

To determine the share of each measured trait in the variance of the study population, as well as reducing the number of studied traits by considering the correlation matrix between the measured traits and indices, the principal component analysis method was used. Under drought stress conditions at the beginning of the vegetative stage, the results showed that the first four main components had specific values greater than one and together accounted for $86.19 \%$ of the diversity in the study population (Table 6, Figure 2a). Based on the high and positive specific values related to biological yield (BY), spike mass (SM), grain mass per plant (GMP) and total plant biomass (TPB) in the first component, the first component can be considered related to the yield of genotypes. In the second component, the highest eigenvalues were related to MP, GMP and STI indices, genotype yield under non-stress conditions (YP), 1000-grain mass (TGW) and genotype yield during drought stress conditions at the beginning of vegetative stage (YS1). The second component can be introduced as a component related to the response to sensitivity or tolerance to drought stress. The third component had the highest coefficients for deep root mass (DRM), total deep root length (TDRL), root biomass (RBio) and longest root (LR). According to these

Table 5: Independent comparison test between two groups of genotypes based on total rank of mean RM(T)

Independent comparison based on grain yield trait per-plant

\begin{tabular}{llllll} 
contrast & Df & Contrast ss & Mean Square & F value & P r $>$ F \\
\hline One & 1 & 2369.8 & 2369.8 & 11.77 & 0.0007 \\
\hline
\end{tabular}




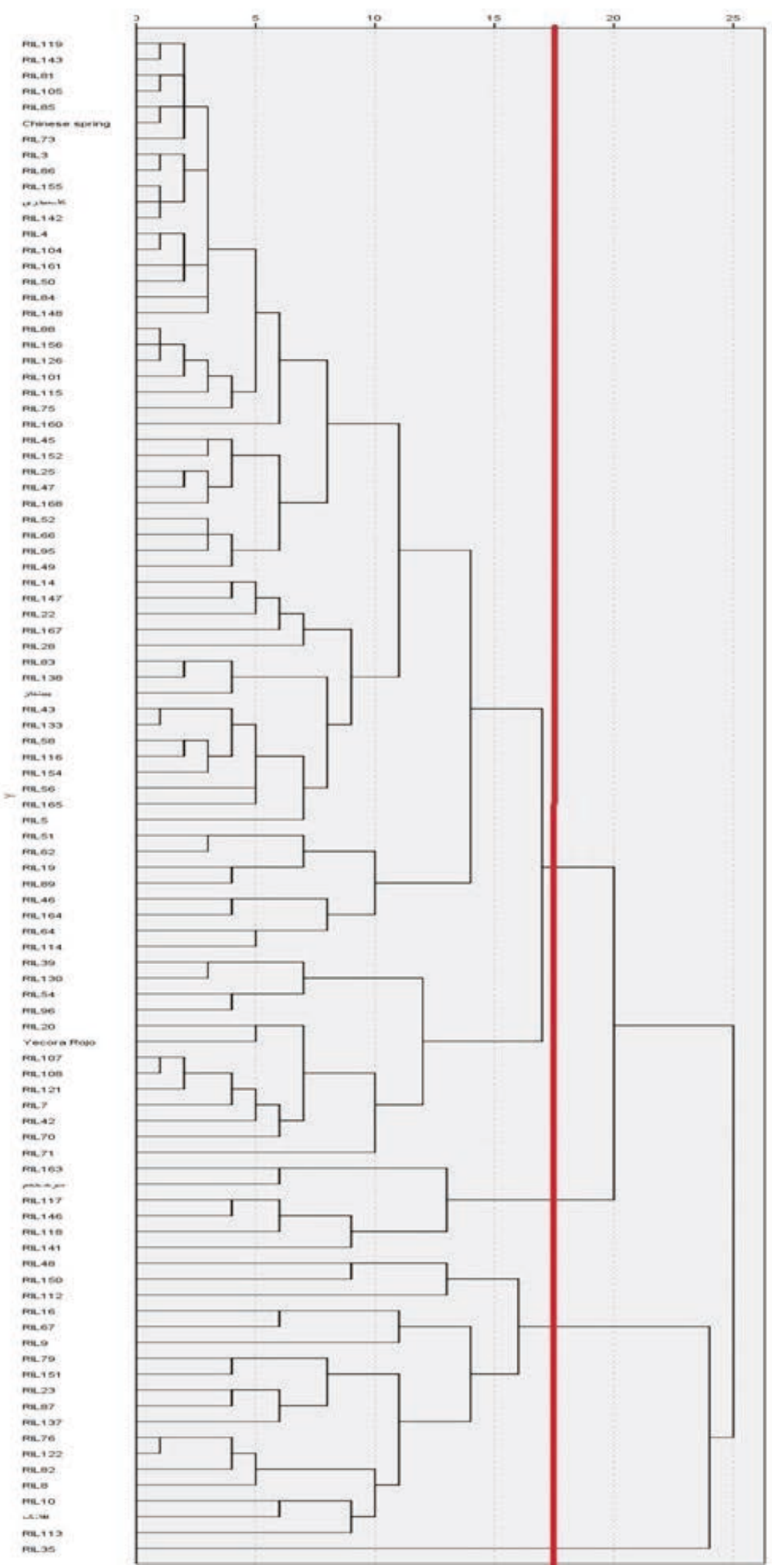

Figure 1: Cluster analysis of 96 genotypes based on data obtained from measuring all traits 
Table 6: Principal component analysis using evaluation traits under drought stress conditions at the beginning of the vegetative stage

\begin{tabular}{|c|c|c|c|c|c|}
\hline Characteristics & Abbreviation & $\begin{array}{l}\text { First } \\
\text { component }\end{array}$ & $\begin{array}{l}\text { Second } \\
\text { component }\end{array}$ & $\begin{array}{l}\text { Third } \\
\text { component }\end{array}$ & $\begin{array}{l}\text { Fourth } \\
\text { component }\end{array}$ \\
\hline Biological yeild (g) & BY & 0.96 & -0.20 & -0.10 & \\
\hline Spike mass (g) & SW & 0.88 & -0.21 & -0.24 & 0.28 \\
\hline Grain mass per-plant (g) & GWP & 0.88 & -0.24 & -0.23 & 0.30 \\
\hline Total plant biomass (g) & TPB & 0.87 & -0.36 & 0.25 & 0.10 \\
\hline $\begin{array}{l}\text { Ratio of root biomass to total } \\
\text { plant biomass }\end{array}$ & RRT & -0.74 & & 0.59 & 0.21 \\
\hline Number of grain per-spike & NGS & 0.68 & -0.58 & -0.29 & 0.26 \\
\hline Ratio of root to shoot & RRS & -0.65 & -0.10 & 0.64 & 0.26 \\
\hline Mean productivity & $\operatorname{MP}(1)$ & 0.37 & 0.87 & 0.24 & 0.10 \\
\hline Geometric mean productivity & GMP(1) & 0.41 & 0.86 & 0.23 & 0.14 \\
\hline Stress tolerance index & $\operatorname{STI}(1)$ & 0.44 & 0.85 & 0.20 & 0.15 \\
\hline $\begin{array}{l}\text { Yield genotypes under normal } \\
\text { conditions }(\mathrm{g})\end{array}$ & YP & 0.11 & 0.83 & 0.28 & \\
\hline Thousand grain mass (g) & TGW & 0.54 & 0.74 & 0.15 & 0.22 \\
\hline Number of spikelets per-spike & NSS & 0.59 & -0.60 & -0.33 & 0.28 \\
\hline Deep root dry mass (g) & DRW & 0.15 & -0.41 & 0.81 & 0.23 \\
\hline Total deep roots length $(\mathrm{cm})$ & TDRL & 0.15 & -0.39 & 0.80 & 0.15 \\
\hline Root biomass (g) & Rbio & 0.21 & -0.44 & 0.80 & 0.24 \\
\hline longest root $(\mathrm{cm})$ & LR & & -0.29 & 0.71 & \\
\hline Spike length $(\mathrm{cm})$ & SP & 0.55 & -0.11 & 0.31 & -0.72 \\
\hline $\begin{array}{l}\text { Yield genotypes under stress conditions } \\
\text { at the beginning of the vegetative stage (g) }\end{array}$ & YS(1) & 0.54 & 0.74 & 0.15 & 0.22 \\
\hline Stem dry mass (g) & SDW & 0.56 & & 0.30 & -0.72 \\
\hline Plant height $(\mathrm{cm})$ & $\mathrm{PH}$ & 0.55 & & 0.33 & -0.69 \\
\hline Shallow root mass (g) & SRW & 0.22 & -0.22 & 0.23 & 0.12 \\
\hline $\begin{array}{l}\text { Ratio of number of grain to number of } \\
\text { spikelets per spike }\end{array}$ & RNN & 0.48 & & & \\
\hline Eigen value & & 7.51 & 5.73 & 4.26 & 2.13 \\
\hline Variance (\%) & & 32.69 & 24.95 & 18.54 & 10.00 \\
\hline Cumulative variance (\%) & & 32.69 & 57.64 & 76.19 & 86.19 \\
\hline
\end{tabular}

Table 7: Principal component analysis using evaluation traits under drought stress conditions at the beginning of the reproductive stage

\begin{tabular}{|c|c|c|c|c|c|}
\hline Characteristics & Abbreviation & $\begin{array}{l}\text { First } \\
\text { component }\end{array}$ & $\begin{array}{l}\text { Second } \\
\text { component }\end{array}$ & $\begin{array}{l}\text { Third } \\
\text { component }\end{array}$ & $\begin{array}{l}\text { Fourth } \\
\text { component }\end{array}$ \\
\hline Biological yeild (g) & BY & 0.95 & 0.22 & & 0.16 \\
\hline Spike mass (g) & SW & 0.91 & 0.18 & & 0.33 \\
\hline Grain mass per-plant (g) & GWP & 0.91 & 0.19 & & 0.33 \\
\hline Total plant biomass (g) & $\mathrm{TPB}$ & 0.86 & 0.21 & 0.39 & 0.18 \\
\hline $\begin{array}{l}\text { Ratio of root biomass to total } \\
\text { plant biomass }\end{array}$ & RRT & -0.81 & -0.16 & 0.53 & \\
\hline Number of grain per-spike & NGS & 0.89 & -0.36 & & 0.21 \\
\hline
\end{tabular}




\begin{tabular}{|c|c|c|c|c|c|}
\hline \multicolumn{6}{|l|}{ Continued } \\
\hline Ratio of root to shoot & RRS & -0.79 & -0.17 & 0.47 & \\
\hline Mean productivity & $\mathrm{MP}(2)$ & -0.18 & 0.97 & & \\
\hline Geometric mean productivity & GMP(2) & -0.16 & 0.98 & & \\
\hline Stress tolerance index & $\operatorname{STI}(2)$ & -0.15 & 0.97 & & \\
\hline $\begin{array}{l}\text { Yield genotypes under normal } \\
\text { conditions }(\mathrm{g})\end{array}$ & YP & -0.25 & 0.94 & & \\
\hline Thousand grain mass (g) & TGW & -0.10 & 0.97 & & \\
\hline Number of spikelets per-spike & NSS & 0.80 & -0.45 & & 0.19 \\
\hline Deep root dry mass (g) & DRW & & & 0.95 & 0.17 \\
\hline Total deep roots length $(\mathrm{cm})$ & TDRL & -0.11 & 0.11 & 0.89 & 0.14 \\
\hline Root biomass (g) & Rbio & & & 0.96 & \\
\hline longest root $(\mathrm{cm})$ & LR & & 0.16 & 0.84 & \\
\hline Spike length $(\mathrm{cm})$ & SP & 0.71 & 0.18 & 0.22 & -0.56 \\
\hline $\begin{array}{l}\text { Yield genotypes under stress at the } \\
\text { beginning of the reproductive stage (g) }\end{array}$ & YS(2) & -0.10 & 0.97 & & \\
\hline Stem dry mass (g) & SDW & 0.66 & 0.28 & 0.22 & -0.62 \\
\hline Plant height $(\mathrm{cm})$ & $\mathrm{PH}$ & 0.62 & 0.28 & 0.24 & -0.63 \\
\hline Shallow root mass (g) & SRW & 0.12 & & 0.25 & -0.25 \\
\hline $\begin{array}{l}\text { Ratio of number of grain to number of } \\
\text { spikelets per spike }\end{array}$ & RNN & 0.53 & 0.20 & -0.15 & \\
\hline Eigen value & & 7.87 & 6.52 & 4.31 & 1.65 \\
\hline Variance (\%) & & 34.24 & 28.35 & 18.74 & 07.20 \\
\hline Cumulative variance (\%) & & 34.24 & 62.59 & 81.33 & 88.54 \\
\hline
\end{tabular}

Table 8: Principal component analysis using evaluation traits under no drought stress conditions

\begin{tabular}{llllll}
\hline Characteristics & Abbreviation & $\begin{array}{l}\text { First } \\
\text { component }\end{array}$ & $\begin{array}{l}\text { Second } \\
\text { component }\end{array}$ & $\begin{array}{l}\text { Third } \\
\text { component }\end{array}$ & $\begin{array}{l}\text { Fourth } \\
\text { component }\end{array}$ \\
\hline Biological yeild (g) & BY & 0.93 & -0.25 & 0.19 & \\
Spike mass (g) & SW & 0.87 & -0.34 & 0.21 & 0.24 \\
Grain mass per-plant (g) & GWP & 0.87 & -0.33 & 0.22 & 0.24 \\
Total plant biomass (g) & TPB & 0.96 & & 0.15 & 0.13 \\
Ratio of root biomass to Total & RRT & -0.43 & 0.87 & -0.14 & \\
plant biomass & NGS & 0.73 & -0.32 & -0.55 & 0.19 \\
Number of grain per-spike & RRS & -0.46 & 0.83 & -0.13 & \\
Ratio of root to shoot & TGW & & & 0.99 & \\
Thousand grain mass (g) & NSS & 0.70 & -0.29 & -0.58 & 0.14 \\
Number of spikelets per-spike & DRW & 0.48 & 0.79 & & 0.14 \\
Deep root dry mass (g) & TDRL & 0.54 & 0.75 & & \\
Total deep roots length (cm) & Rbio & 0.51 & 0.82 & & 0.16 \\
Root biomass (g) & LR & 0.54 & 0.70 & & 0.12 \\
longest root (cm) & SP & 0.74 & & & -0.54 \\
Spike length (cm) & SDW & 0.72 & 0.25 & & -0.56 \\
Stem dry mass (g) & PH & 0.72 & 0.11 & & -0.58 \\
Plant height (cm) & & & & \\
\hline
\end{tabular}




\begin{tabular}{lllll}
\hline Continued & & & & \\
\hline Shallow rootmass(g) & SRW & 0.30 & 0.46 & 0.13 \\
$\begin{array}{l}\text { Ratio of number of grain to number } \\
\text { of spikelets per spike }\end{array}$ & RNN & 0.37 & -0.25 & 0.26 \\
$\begin{array}{l}\text { Eigen value } \\
\text { Variance (\%) }\end{array}$ & & & \\
Cumulative variance (\%) & 7.70 & 4.67 & 2.83 & 1.32 \\
\hline
\end{tabular}
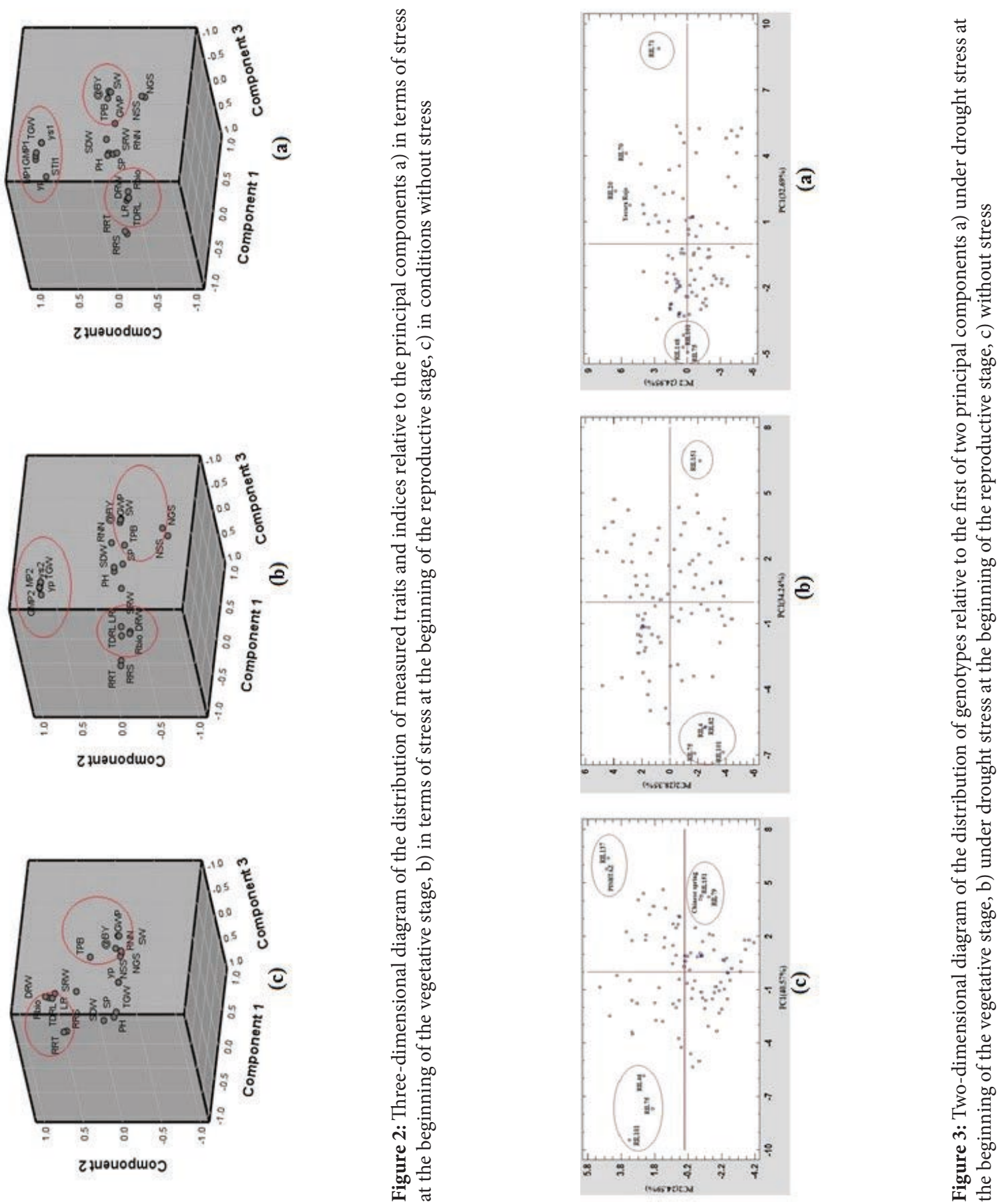
results, the third component related to root traits is considered.

Based on the output of principal components during drought stress conditions at the beginning of the vegetative stage, it can be concluded that based on the first and second components and considering the distribution of genotypes relative to the first two components, genotypes that in terms of the first component, they have the highest value, have more performance during stress conditions, and also according to the second component, the reaction of these genotypes to drought stress at the beginning of the vegetative stage will be visible. Accordingly, the genotypes at the far right of the graph (Figure 3a) have a high yield and are more tolerant to drought stress at the beginning of the growing stage. These are low-yield, drought-sensitive genotypes when drought stress was applied at the beginning of the growing stage.

The results of principal component analysis during drought stress conditions at the beginning of the reproductive stage are shown in Figures (2b) and (3b). As in the case of stress at the beginning of the vegetative stage, here too the first four components had specific values greater than one, describing a total of $88.54 \%$ of the diversity in the study population (Table 7). Due to the higher and positive eigenvalues for biological yield (BY), grain mass per plant (GMP), spike mass (SM), number of grains per spike (NGS) and total plant biomass (TPB) in the first component, can be The first component was related to the performance of the population. The highest eigenvalues in the second component are related to GMP, MP, STI, 1000-grain mass (TGM) indices, genotype yield during drought stress conditions at the beginning of reproductive stage (YS2) and genotype yield under non-stress conditions (YP). Conditions also, we define the second component as the component related to the response of susceptibility or tolerance of genotypes to drought stress at the beginning of the reproductive stage. In the third component, the highest coefficients were related to root biomass (RBio), deep root mass (DRM), total deep root length (TDRL) and longest root (LR). As a result, the third component related to the diversity of root traits was considered.

Under stress-free conditions, the results of principal component analysis showed that the first four principal components with eigenvalues greater than one, in total, accounted for $87.05 \%$ of the variance in the population of the recombinant inbred lines studied (Table 8). Accordingly, the first component with total plant biomass (TPB), biological yield (BY), grain mass per plant (GMP) and spike mass (SM), justified $40.57 \%$ of the diversity in the population (Figure 2c). Therefore, even in stress-free conditions, the first component can be introduced related to the performance of genotypes. The second compo- nent with a justification of $24.59 \%$ of the diversity of the study population and the highest specific values related to the traits of root to plant biomass ratio (RRT), root to shoot ratio (RRS), root biomass (RBio), deep root mass (DRM) and the sum of deep root lengths (TDRL), could be introduced as a component of root traits.

The result of principal component analysis output under stress-free conditions showed that based on the first and second components and considering the distribution of genotypes relative to the first two components, it is possible to identify genotypes that have the highest yield under conditions. No stress in terms of root traits had the best reaction and vice versa (Figure 3c).

\section{CONCLUSION}

Despite the significant difference in the level of $1 \%$ probability between genotypes and also the interaction of genotype with environmental conditions, for all root traits except shallow root dry mass, understanding the response of these traits to the types of drought stress was high complicated. For example, the longest root trait decreased by $13.3 \%$ compared to stress-free conditions at the beginning of the vegetative stage, while the same trait increased by $4.9 \%$ compared to non-stress conditions at the beginning of the reproductive stage. Also, in the case of root biomass trait during stress application at the beginning of the vegetative stage compared to the non-stress state decreased by $13.1 \%$, while the same trait increased by $3.4 \%$ during stress application at the reproductive stage. However, finding a successful combination of shoot and root traits that can be used in breeding to improve further growth and productivity is a big challenge, because in the present study, the response of the wheat plant to many stages It is different from stressful growth and even in some cases contradictory.

\section{REFERENCES}

Ali, M. B. and A. N. El-Sadek. (2016). Evaluation of drought tolerance indices for wheat (Triticum aestivum L.) under irrigated and rainfed conditions. Communications in Biometry and Crop Science, 11(1), 77-89.

Bardgett, R. D., L. Mommer and F. T. De-Vries. (2014). Going underground: root traits as drivers of ecosystem processes. Trends in Ecology \& Evolution, 29(12), 692-699. https://doi. org/10.1016/j.tree.2014.10.006

Dalal, M., S. Sahu, S. Tiwari, A. R. Rao and K. Gaikwad. (2018). Transcriptome analysis reveals interplay between hormones, ROS metabolism and cell wall biosynthesis for drought-induced root growth in wheat. Plant Physiology 
and Biochemistry,130, 482-492. https://doi.org/10.1016/j. plaphy.2018.07.035

Ehdaie, B., A. P. Layne and J. G. Waines. (2012). Root system plasticity to drought influences grain yield in bread wheat. Euphytica, 186, 219-232. https://doi.org/10.1007/s10681011-0585-9

Ehdaie, B., S. A. Mohammadi and M. Nouraein. (2016). QTLs for root traits at mid-tillering and for root and shoot traits at maturity in a RIL population of spring bread wheat grown under well-watered conditions. Euphytica, 211(1), 17-38. https://doi.org/10.1007/s10681-016-1670-x

Ehdaie, B. and J. G. Waines. (1994). Genetic analysis of carbon isotope discrimination and agronomic characters in a bread wheat cross. Theoretical and Applied Genetics, 88(8), 1023-1028. https://doi.org/10.1007/BF00220811

Gao, Y. and J. P. Lynch. (2016). Reduced crown root number improves water acquisition under water deficit stress in maize (Zea mays L.). Journal of Experimental Botany, 67(15), 4545-4557. https://doi.org/10.1093/jxb/erw243

Ghassemi-Golezani, K., S. Heydari and B. Dalil. (2018). Field performance of maize (Zea mays L.) cultivars under drought stress. Acta agriculturae Slovenica, 111(1), 25-32. https://doi.org/10.14720/aas.2018.111.1.03

Hammer, G. L., Z. Dong, G. McLean, A. Doherty, C. Messina, J. Schussler, C. Zinselmeier, S. Paszkiewicz and M. Cooper. (2009). Can changes in canopy and/or root system architecture explain historical maize yield trends in the US corn belt. Crop Science, 49(1), 299-312. https://doi.org/10.2135/ cropsci2008.03.0152

Hassani, F. (2016). Evalution of terminal drought tolerance and validation of its related EST-SSRs in bread wheat. Thesis for the degree of Ph. D. in Plant Breeding, Shahre-kord university, Iran. (In Persian with English abstract).

Heidari, Z. (2012). Determination of chromosomal position of genes controlling some physiological traits related to drought resistance in bread wheat (Triticum aestivum) and their relationship with root traits, using selected alternative lines. Thesis for the degree of M.Sc. in Plant Breeding, Shahre-kord university, Iran. (In Persian with English abstract)

Jin, K., J. Shen, R. W. Ashton, R. P. White, I. C. Dodd, M. A. Parry and W. R. Whalley. (2015a). Wheat root growth responses to horizontal stratification of fertiliser in a water-limited environment. Plant and Soil, 386(1-2), 77-88. https://doi. org/10.1007/s11104-014-2249-8

Jin, K., J. Shen, R. W. Ashton, R. P. White, I. C. Dodd, A. L. Phillips, M. A. Parry and W. R. Whalley. (2015b). The effect of impedance to root growth on plant architecture in wheat. Plant and Soil, 392(1-2), 323-332. https://doi.org/10.1007/ s11104-015-2462-0

Jin, Z., X. Qing-wu, K. E. Jessup, H. Xiao-bo, H. Bao-zhen, T. H. Marek, X. Wenwei, S. R. Evett, S. A. O'Shaughnessy and D. K. Brauer. (2018). Shoot and root traits in drought tolerant maize (Zea mays L.) hybrids. Journal of Integrative Agriculture, 5(17), 1093-1105. https://doi.org/10.1016/S20953119(17)61869-0

Kadam, S., K. Singh, S. Shukla, S. Goel, P. Vikram, V. Pawar,
K. Gaikwad, R. Khanna-Chopra and N. Singh. (2012). Genomic associations for drought tolerance on the short arm of wheat chromosome 4B. Functional \& Integrative Genomics, 12(3), 447-464. https://doi.org/10.1007/s10142012-0276-1

Khosravi, S., R. Azizinezhad, A. Baghizadeh and M. Maleki. (2020). Evaluation and comparison of drought tolerance in some wild diploid populations, tetraploid and hexaploid cultivars of wheat using stress tolerance indices. Acta agriculturae Slovenica, 115(1), 105-112. https://doi. org/10.14720/aas.2020.115.1.1336

Koolacharta, R., S. Jogloya, N. Vorasoota, S. Wongkaewb, C. C. Holbrookc, N. Jongrungklanga, T. Kesmalaa and A. Patanothaia. (2013). Rooting traits of peanut genotypes with different yield responses to terminal drought. Field Crops Research, 149, 366-378. https://doi.org/10.1016/j. fcr.2013.05.024

Mohammadi, R. and A. Abdulahi. (2017). Evaluation of durum wheat genotypes based on drought tolerance indices under different levels of drought stress. Journal of Agricultural Sciences, Belgrade, 62(1), 1-14. https://doi.org/10.2298/ JAS1701001M

Nadeem, M., J. Li, M. Yahya, A. Sher, C. Ma, X. Wang and L. Qiu. (2019). Research progress and perspective on drought stress in legumes: a review. International Journal of Molecular Sciences, 20(10), 1-32. https://doi.org/10.3390/ ijms20102541

Richards, R. A. (2008). Genetic opportunities to improve cereal root systems for dryland agriculture. Plant Production Science, 11, 12-16. https://doi.org/10.1626/pps.11.12

Shanker, A. K., M. Maheswari, S. k. Yadav, S. Desai, D. Bhanu, N. B. Attal and B. Venkateswarlu (2014). Drought stress responses in crops. Functional \& Integrative Genomics, 14(1), 11-22. https://doi.org/10.1007/s10142-013-0356-x

Harma, S., S. Z. Xu, B. Ehdaie, A. Hoops, T. J. Close, A. J. Lukaszewski and J. G. Waines. (2011). Dissection of QTL effects for root traits using a chromosome arm-specific mapping population in bread wheat. Theoretical and Applied Genetics, 122, 759-769. https://doi.org/10.1007/s00122010-1484-5

Sinha, R., V. Irulappan, B. Mohan-Raju, A. Suganthi and M. Senthil-Kumar. (2019). Impact of drought stress on simultaneously occurring pathogen infection in field-grown chickpea. ScientificReports, 9(1), 1-15. https://doi.org/10.1038/ s41598-019-41463-Z

Sofi, P. A., M. Djanaguiraman, K. H. M. Siddique and P. V. V. Prasad. (2018). Reproductive fitness in common bean (Phaseolus vulgaris L.) under drought stress is associated with root length and volume. Indian Journal of Plant Physiology, 23(4), 796-809. https://doi.org/10.1007/s40502-018-0429-x

Thangthonga N., S. Jogloya, V. Pensukb, T. Kesmalaa and N. Vorasoot. (2016). Distribution patterns of peanut roots under different durations ofearly season drought stress. Field Crops Research, 198, 40-49. https://doi.org/10.1016/j. fcr.2016.08.019 